\title{
Freund's adjuvant-induced inflammation: clinical findings and its effect on hepcidin mRNA expression in horses ${ }^{1}$
}

\author{
José P. Oliveira-Filho²*, Peres R. Badial², Paulo Henrique J. Cunha ${ }^{3}$, Ana Paula Bordon ${ }^{4}$, \\ João P. Araujo Jr ${ }^{4}$, Thomas J. Divers ${ }^{5}$, Nena J. Winand ${ }^{5}$ and Alexandre S. Borges ${ }^{2}$
}

\begin{abstract}
Oliveira-Filho J.P., Badial P.R., Cunha P.H.J., Bordon A.P., Araujo Jr J.P., Divers T.J., Winand N.J. \& Borges A.S. 2014. Freund's adjuvant-induced inflammation: clinical findings and its effect on hepcidin mRNA expression in horses. Pesquisa Veterinária Brasileira 34(1):51-56. Departamento de Clínica Veterinária, Faculdade de Medicina Veterinária e Zootecnia, Universidade Estadual Paulista, Campus de Botucatu, Distrito de Rubião Júnior s/n, Botucatu, SP 18618-000, Brazil. E-mail: zefilho@fmvz.unesp.br

Hypoferremia observed during systemic inflammatory disorders is regulated by hepcidin. Hepcidin up-regulation is particularly important during acute inflammation, as it restricts the availability of iron, which is necessary for pathogenic microorganism growth before adaptive immunity occurs. The aim of this study was to evaluate the clinical findings and hepatic hepcidin mRNA expression in horses using a Freund's complete adjuvant (FCA) model of inflammation. The expression of hepcidin mRNA in the liver was determined in healthy horses following two intramuscular injections of FCA at $0 \mathrm{~h}$ and $12 \mathrm{~h}$. Plasma iron and fibrinogen concentrations were measured at multiple time points between $0 \mathrm{~h}$ and $240 \mathrm{~h}$ post-FCA injection (PI). Hepcidin mRNA expression was determined by RT-qPCR using liver biopsy samples performed at $0 \mathrm{~h}$ (control), $6 \mathrm{~h}$ and $18 \mathrm{~h}$ PI. The mean plasma fibrinogen level was significantly different from the control values only between 120 and $216 \mathrm{~h}$ PI. The mean plasma iron level was significantly lower than the control between 16 and $72 \mathrm{~h} \mathrm{PI}$, reaching the lowest levels at $30 \mathrm{~h}$ PI ( $33 \%$ of the initial value), and returned to the reference value from $96 \mathrm{~h}$ PI to the end of the experiment. Hepcidin mRNA expression increased at $6 \mathrm{~h}$ PI and remained high at $18 \mathrm{~h} \mathrm{PI}$. The iron plasma concentration was an earlier indicator of inflammatory processes in horses when compared with fibrinogen and might be useful for the early detection of inflammation in the horse. FCA administration caused the rapid onset of hypoferremia, and this effect was likely the result of up-regulated hepatic hepcidin gene expression. This study emphasizes the importance of hepcidin and iron metabolism during inflammation in horses.
\end{abstract}

INDEXS TERMS: Hepcidin, Freund's adjuvant, acute-phase reactants, inflammation, iron metabolism, horses.

RESUMO.- [Inflamação induzida por Adjuvante de Freund: achados clínicos e efeitos sobre a expressão do RNAm da

\footnotetext{
${ }^{1}$ Received on July 7, 2013.

Accepted for publication on January 14, 2014.

${ }^{2}$ Departamento de Clínica Veterinária, Faculdade de Medicina Veterinária e Zootecnia, Universidade Estadual Paulista (Unesp), Campus de Botucatu, Distrito de Rubião Júnior s/n, Botucatu, SP 18618-000, Brazil. *Corresponding author: zefilho@fmvz.unesp.br

${ }^{3}$ Departamento de Medicina Veterinária, Escola de Veterinária, Universidade Federal de Goiás (UFG), Campus Samambaia (Campus II), Cx. Postal 131, Goiânia, GO 74001-970, Brazil.

${ }^{4}$ Departamento de Microbiologia e Imunologia, Instituto de Biociência de Botucatu, Unesp, Campus de Botucatu, Distrito de Rubião Júnior s/n, Botucatu, SP 18618-000, Brazil.

${ }^{5}$ Cornell University, Ithaca, NY 14853, USA.
}

hepcidina em equinos.] A hipoferremia observada durante os processos inflamatórios sistêmicos é mediada pela hepcidina. 0 aumento da expressão da hepcidina é particularmente importante durante a inflamação aguda, por restringir a disponibilidade de ferro necessária para o crescimento de microrganismos patogênicos antes que a imunidade adaptativa ocorra. $\mathrm{O}$ objetivo deste estudo foi avaliar os achados clínicos e a expressão hepática do RNA mensageiro (RNAm) da hepcidina em cavalos após a indução da inflamação com Adjuvante completo de Freund (FCA). A expressão hepática do RNAm da hepcidina foi determinada em cavalos sadios após duas administrações intramusculares de FCA às $0 \mathrm{~h}(\mathrm{M} 0) \mathrm{e}$ $12 \mathrm{~h}$ (M12). As concentrações plasmáticas de ferro e fibrinogênio foram mensuradas em múltiplos momentos entre $0 \mathrm{~h}$ 
e 240 h (M240) após a primeira administração de FCA (PI). A expressão do RNAm da hepcidina foi determinada por RT-qPCR usando amostras de biopsias hepáticas colhidas as $0 \mathrm{~h}$ (controle), 6 h (M6) e 18 h (M18) PI. A concentração plasmática média de fibrinogênio foi estatisticamente diferente do M0 entre 120 h e 216 h PI. A concentração plasmática média de ferro foi significantemente menor que o controle entre $16 \mathrm{~h}$ e $72 \mathrm{~h} \mathrm{PI}$, alcançou o nível mais baixo às $30 \mathrm{~h}$ PI $(33 \%$ do valor inicial) e retornou aos valores de referência entre $96 \mathrm{~h}$ PI e até o final do experimento. A expressão do RNAm da hepcidina aumentou no M6 e permaneceu alta no M18. A concentração plasmática de ferro foi um indicador precoce da inflamação quando comparada com o fibrinogênio e pode ser útil na detecção precoce da inflamação em cavalos. A administração do FCA causou um rápido início da hipoferremia, e isto foi resultante do aumento da expressão hepática da hepcidina. Estes resultados enfatizam a importância da hepcidina e do metabolismo do ferro durante a inflamação em cavalos.

TERMOS DE INDEXAÇÃO: Hepcidina, Adjuvante completo de Freund, reagente de fase aguda, inflamação, metabolismo do ferro, cavalo.

\section{INTRODUCTION}

Iron plays an indispensable role in various physiological processes due to its capacity to easily accept and donate electrons when converting between the ferrous $(\mathrm{Fe} 2+)$ and ferric $(\mathrm{Fe} 3+$ ) forms (Schaefer 2009). Iron acquisition is critical for bacterial growth during infection, and bacterial pathogenicity is greatly enhanced by freely available iron (Bullen et al. 2005). Viral replication is associated with enhanced cellular metabolism, and this process also requires host iron (Drakesmith \& Prentice 2008). The hypoferremia observed during inflammation or infection is an innate host defense mechanism that limits the availability of this element to pathogenic microbes (Radtke \& O'Riordan 2006). The rapid drop in iron concentration during inflammation in vertebrates is mediated by hepcidin, a 25 amino acid peptide that is synthesized primarily in the liver. Hepcidin binds to the iron exporter, ferroportin, causing the internalization and degradation of this molecule. Consequently, iron is sequestered within macrophages and cannot be absorbed by intestinal cells (Darshan \& Anderson 2009).

The role of hepcidin and its relation to innate immunity and iron metabolism have been previously demonstrated in mammalian species (Nicolas et al. 2002, Kemna et al. 2005, Sang et al. 2006, Sheikh et al. 2007, Wang et al. 2008). Recently, we cloned and sequenced equine hepcidin mRNA (Oliveira-Filho et al. 2010a) and demonstrated a link between hepcidin and hypoferremia in horses that had been treated with lipopolysaccharide (LPS) (Oliveira-Filho et al. 2012).

It is known that hypoferremia can be induced in horses during inflammation, such as after the administration of Freund's complete adjuvant (FCA) (Auer et al. 1989, Mills et al. 1997, Mills et al. 1998) and occurs before elevation in plasma fibrinogen. Therefore, the aim of this study was to evaluate the clinical findings and hepcidin gene expression in the livers of healthy horses using an FCA model of inflammation.

\section{MATERIALS AND METHODS}

Experimental animals. Six adult, non-pregnant, Quarter Horse mares with $10.0( \pm 0.8)$ years old and had a mean body weight of $417.0( \pm 11.0) \mathrm{kg}$ were used for this study. The mares were housed in individual stalls and received hay and water ad libitum. They had normal physical exam findings, complete blood counts and plasma iron and fibrinogen concentrations at the time of the initial FCA injection. All experiments were carried out in accordance with the Sao Paulo State University (Unesp-Botucatu) Institutional Animal Care and Use Committee (108-A/2007).

Induction of inflammation. Inflammation was induced in six mares via two intramuscular injections of $5.0 \mathrm{~mL}$ of FCA into the serratus ventralis muscle (right neck) at $0 \mathrm{~h}$ and $12 \mathrm{~h}$. All of horses received the first FCA administration at $08.00 \mathrm{~h}$ (a.m.).

Physical examination. A clinician (JPOF) examined all of animals at baseline (sampling time $0 \mathrm{~h}$, immediately before the first FCA injection) and at 2, 4, 6, 8, 12, 16, 18, 20, 24, 30, 36, 42, 48, $60,72,96,120,144,168,192,216$, and $240 \mathrm{~h}$ post-FCA injection (PI). Pain, edema, and temperature at the FCA injection site were monitored. Skin temperature at the FCA injection site was measured using a digital infrared thermometer (TAT 2.000C, Exergen ${ }^{\mathrm{TM}}$, Watertown, USA). Three successive temperature measurements were made by placing the thermometer probe on the FCA injection site and keeping it in contact with the skin until temperature readings were taken. A mean was then calculated and recorded for each experimental point.

Pain at the FCA injection site was classified according to a pain scale that included the following four grades: zero (normal: no reaction to palpation); one (mild pain: mild reaction to palpation, abnormal facial expression in response to touch, no reluctance to move the neck or head); two (moderate pain: resistance to palpation, abnormal facial expression in response to touch, reluctance to move the neck or head, restlessness), and three (severe pain: violent reaction to palpation, abnormal facial expression in response to touch, no voluntary movement of the neck or head).

The rectal temperature, color changes of the oral and vaginal mucosa, capillary refill time, intestinal motility, heart and respiratory rates were also measured and recorded for each individual. Body weight was measured at $0 \mathrm{~h}$ and at $240 \mathrm{~h}$ PI. The ambient temperature was measured during the experiment (TermoHigro digital SH122, JProlab ${ }^{\circledR}$, São José dos Pinhais, Brazil), and data concerning the relative humidity of air were obtained from the Estação Meteorológica do Depto. de Solos e Recursos Ambientais - Faculdade de Ciências Agronômicas - UNESP.

Blood analyses. Peripheral blood samples were collected after every physical exam into vacuum tubes with ethylenediaminetetraacetic acid (EDTA) for packed cell volume (PCV) measurements, white blood cell (WBC) counts and plasma fibrinogen concentrations, and with sodium heparin for iron analysis. The WBC counts were performed at $0,6,24,48,72,96,168$, and 240 h PI.

The blood samples with EDTA were processed immediately after blood collection. The PCV was determined by centrifugation using the microhematocrit method, and the plasma fibrinogen concentration was determined by a heat-precipitation refractometry method. An automated hematology analyzer (Hemascre$\mathrm{en}^{\circledR}$ 18, $\operatorname{Ebran}^{\circledR}$, São Paulo, Brazil), was used to perform the WBC counts. The heparinized blood samples were centrifuged, and the plasma was obtained and stored at $-80{ }^{\circ} \mathrm{C}$ until analysis. The plasma was thawed, and the iron concentration was determined in duplicate using a semi-automated chemistry analyzer (SB-190, Celm ${ }^{\circledR}$, Barueri, Brazil), with Ferro Chromazurol reagent.

RNA purification, reverse transcription and RT-qPCR. Liver biopsies were performed immediately prior to infection $(0 \mathrm{~h}$, control) and at $6 \mathrm{~h}$ and $18 \mathrm{~h}$ PI. Biopsy tissues were frozen in li- 
quid nitrogen and stored at $-80^{\circ} \mathrm{C}$ until processing. Total RNA purification, DNase treatment, and cDNA synthesis were performed using methodology that has been previously described (Oliveira-Filho et al. 2012). The relative quantification of hepcidin mRNA in the liver samples was performed using the comparative $\mathrm{Ct}$ method ( $2^{-\Delta \Delta \mathrm{Ct}}$ method) that was developed for relative real-time PCR data processing with a Real-Time PCR System (7300, Applied Biosystems ${ }^{\mathrm{TM}}$, Carlsbad, USA) and the Real-Time PCR Master Mix (Power SYBR ${ }^{\circledR}$ Green, Applied Biosystems ${ }^{\mathrm{TM}}$ ). The quantities of the target gene in the liver samples at $6 \mathrm{~h}$ and $18 \mathrm{~h}$ PI were calculated relative to the calibrator sample (at $0 \mathrm{~h}$ ). The primer sets used in the quantitative real-time RT-PCR (RT-qPCR) for detection of the equine hepcidin (GenBank:GQ253624) and $\beta$-actin (GenBank:AF035774.1) mRNAs and the thermocycler conditions have been previously described (Oliveira-Filho et al. 2010a). A "no template" control in duplicate was included on each plate to show that amplicon contamination was absent. Amplification of specific transcripts was confirmed by melting curve profiles generated at the end of each run.

Statistical analysis. For all parameters, the repeated measures ANOVA test with Tukey's post-test was used. The statistical analysis was performed with SAS software 9.2 (SAS Institute, Cary, NC) to determine the statistical significance between the means of multiple time points measured and the mean of the control values. The control values refer to the values obtained before the first FCA injection ( $0 \mathrm{~h})$, with each animal serving as its own control. A P value of $<0.05$ was considered to be statistically significant. The results are presented as the geometric means \pm S.D. (standard deviation), unless otherwise specified.

\section{RESULTS}

Three animals exhibited grade one localized pain from $6 \mathrm{~h}$ to $168 \mathrm{~h} \mathrm{PI}$. The three remaining horses displayed localized pain only after the second administration of FCA at $16 \mathrm{~h} \mathrm{PI}$; of these horses, two exhibited grade three localized pain (from $16 \mathrm{~h}$ to $36 \mathrm{~h} \mathrm{PI}$ ) and one presented grade two localized pain (from $42 \mathrm{~h}$ to $96 \mathrm{~h} \mathrm{PI}$ ). In the latter three horses, the localized pain decreased to grade one between $120 \mathrm{~h}$ and $192 \mathrm{~h}$ PI. At $216 \mathrm{~h} \mathrm{PI}$, no signs of localized pain were observed in any of the experimental animals.

Localized edema was identified at $6(n=2)$ and $8(n=1)$ $\mathrm{h}$ PI in the animals suffering from localized pain after the first administration of FCA and in the remainder of the animals after the second administration of FCA, i.e., $16(n=2)$ and $18(\mathrm{n}=1) \mathrm{h} \mathrm{PI}$, respectively. In five animals, the edema migrated to the pectoral area at $120(n=2)$ and $144(n=3) h$ PI. Nevertheless, no edema or abscesses were observed at the end of the experiment.

The mean temperature at the site of injection (the local temperature) was significantly higher $(\mathrm{p}<0.001)$ than the control at $6 \mathrm{~h}$ PI but was not significantly different from the control values at $12 \mathrm{~h}$ PI ( $p>0.05)$. However, the local temperature increased again after the second administration of FCA and was significantly elevated between 16 and $60 \mathrm{~h}$ PI (Fig.1A). The mean rectal temperature (Fig.1B) did not exceed normal values, i.e., $38.9^{\circ} \mathrm{C}$ (Rose \& Hodgson 2000 ), but was significantly higher between 12 and $60 \mathrm{~h}$ PI when compared with the temperature at $0 \mathrm{~h}(\mathrm{p}<0.001)$. The environmental temperature $\left(23.1 \pm 1.8^{\circ} \mathrm{C}\right)$ and the relative humidity of air $(65.0 \pm 6.7)$ oscillated slightly during the experiment but were not considered to affect the evaluated variables.
No changes in mucosal color, capillary refill time or intestinal motility were observed, and the mean body weight at the end of the experimental period was no different from that measured at the beginning of the experiment. The mean cardiac rate was significantly higher than the control cardiac rate at 18 ( $53.3 \pm 16$ beats per minute) to 30 ( $52.7 \pm 9.0$ beats per minute) h PI (Fig.1C). The respiratory rate was significantly elevated at $30 \mathrm{~h}$ PI $(27.3 \pm 9.0$ breaths per minute) when compared with the control $(\mathrm{p}<0.05)$ (Fig.1C).

The mean PCV value prior to PI was $35.7 \%$ and remained within normal limits during the experiment, but it was near the lower limit from 12 (32.5 \%) to 120 (32.7 \%) h PI. From $144 \mathrm{~h}$ PI until the end of the experiment, the mean PCV returned to a value close to the control value.

The total number of leukocytes and neutrophils increased at $6 \mathrm{~h} \mathrm{PI}$, reaching maximum levels with a leukocytosis $\left(14.7 \times 10^{3}\right.$ cells $\left./ \mu \mathrm{L}, \mathrm{p}<0.01\right)$ and neutrophilia $(10.4 \mathrm{x}$ $10^{3}$ cells $/ \mu \mathrm{L}, \mathrm{p}<0.05$ ) at $48 \mathrm{~h}$ PI that gradually returned to reference values (Fig.1D). The numbers of lymphocytes (Fig.1D), eosinophils, monocytes and basophils were within the normal limits (data not shown).

The mean plasma fibrinogen level was above the reference value of $400.0 \mathrm{mg} / \mathrm{dL}$ (Feldman et al. 2000) between $30 \mathrm{~h}$ and $240 \mathrm{~h}$ PI (Fig. 1E). However, statistically significant differences from control values were found only between $120 \mathrm{~h}$ and $216 \mathrm{~h}$ PI. The mean plasma iron level decreased at $12 \mathrm{~h}$ PI $(87.0 \mu \mathrm{g} / \mathrm{dL})$, representing $70.7 \%$ of the initial value $(124.0 \mu \mathrm{g} / \mathrm{dL}$ ) (Fig.1F) and was significantly lower than the control between $16 \mathrm{~h}$ and $72 \mathrm{~h}$ PI. The mean plasma iron concentration then increased and was within the reference value from $96 \mathrm{~h}$ PI $(74.4 \mu \mathrm{g} / \mathrm{dL})$ to the end of the experiment at $240 \mathrm{~h}$ PI $(83.8 \mu \mathrm{g} / \mathrm{dL})$. The lowest hypoferremic level was detected at $30 \mathrm{~h}$ PI $(40.7 \mu \mathrm{g} / \mathrm{dL})$ $(\mathrm{p}<0.001)$, representing $33 \%$ of the initial value at $0 \mathrm{~h}$. The mean mRNA expression of hepcidin in the liver was significantly elevated at 6 h PI $(2.6 \pm 0.7$-fold $)(\mathrm{p}<0.01)$ and $18 \mathrm{~h}$ PI (2.4 \pm 0.7 -fold) $(\mathrm{p}<0.01)$.

\section{DISCUSSION}

Experimental models using FCA for the induction of inflammatory processes have demonstrated significant decreases in the plasma or serum iron levels in horses (Auer et al. 1989, Mills et al. 1997a). Recently, we verified that the increase in hepatic hepcidin mRNA expression was likely responsible for the hypoferremia observed in horses after LPS injection (Oliveira-Filho et al. 2012). However, this increase was not persistent, and in a few hours, the hepcidin mRNA levels returned to normal. In the current study, the main objective was to verify the increased hepatic hepcidin mRNA expression and its effect on iron metabolism in horses by inducing a more focal inflammatory process using two intramuscular injections of FCA. The hepcidin expression level observed in the present study was more persistent compared with the endotoxemic experimental model induced with LPS (Oliveira-Filho et al. 2012). This likely reflects the different duration of inflammation between the two models.

Mills et al. (1998) administered $2 \mathrm{~mL}$ of FCA on the first, 
second and fifth days of the experiment and, as in our study, observed an increase in edema and temperature at the injection site that reached a maximum at $72 \mathrm{~h}$ after the first dose and diminished by half of the maximum on day 12 . In our work, localized edema was detected at $6 \mathrm{~h} \mathrm{PI}$, but in contrast to the results obtained by Mills et al. (1998), the edema began to resolve on the fifth day (M120), after which, it migrated to the pectoral region and completely disappeared at the end of the experiment. The edema that persisted at the injection site at the end of the experiment by Mills et al. (1998) might have been due to the third injection of FCA on the fifth day of the experiment, despite the lower dosage used by these authors.

The rapid increase in local temperature with three sta- tistically significant peaks at $6 \mathrm{~h}, 30 \mathrm{~h}$, and $60 \mathrm{~h}$ PI as well as the observed edema and localized pain not only represent the classical signs of inflammation but are similar to the results obtained using other protocols for intramuscular administration of FCA in horses (Auer et al. 1989, Mills et al. 1997a, 1997b, Oliveira-Filho et al. 2012).

Mills et al. (1998) observed an elevated temperature in the horses $48 \mathrm{~h}$ after the first dose of FCA, which decreased to normal on the fourth day. These authors observed a second fever peak $24 \mathrm{~h}$ after the second dose of FCA on the sixth day, and the peak disappeared only at the end of the experiment on day 11 . The fever was most likely a consequence of antigenic stimulus and secretion of cytokines by mononuclear phagocytes (Billiau \& Matthys 2001). IFN- $\alpha$,



Fig.1. Mean local (A) and rectal (B) temperature; mean heart rate and respiratory rate (C); mean white blood cells counts (WBC), neutrophil and lymphocyte counts (D); mean plasma fibrinogen (E) and mean plasma iron (F) of the horses in multiple time points after two FCA injections (arrows). ${ }^{*} \mathrm{P}<0.05,{ }^{* *} \mathrm{P}<0.01$, and ${ }^{* * *} \mathrm{P}<0.001$ indicate significant difference from control values $(0 \mathrm{~h})$. When not visible, S.D. bars are smaller than the symbol. 
TNF- $\alpha$, and IL- 1 act as endogenous pyrogenous mediators that stimulate the encephalic thermoregulatory centers to produce a fever (Dinarello 1999). Although the mean rectal temperature of the six animals in our study did not exceed the reference values, the FCA administration caused three peaks of temperature elevation above the control temperature that were close to the upper reference limit. These peaks were considered to be fever-like reactions when taken together with the other systemic signs of inflammation (local edema, pain, and increased temperature).

In our study, no signs of dehydration, color changes of the mucosa, altered capillary refill time or intestinal motility were detected. As in other studies (Mills et al. 1997b, Mills et al. 1998), most of the animals suffered only mild to moderate discomfort that was not sufficient to interrupt food intake or water consumption. As a result, weight loss was not observed after ten days of the experiment. Nevertheless, the animals in our study experienced moderate tachycardia and tachypnea up to three days after FCA injection, most likely associated with pain. Neither the cardiac nor the respiratory rates were described in previous study (Mills et al. 1998).

In our study, a numerical decline in the mean PCV value was observed beginning at $8 \mathrm{~h} \mathrm{PI}$, but this value was neither lower than the reference limits (Feldman et al. 2000) nor significantly different from the value obtained at $0 \mathrm{~h}$. However, the mean PCV value was close to the lower limit from $8 \mathrm{~h}$ to $120 \mathrm{~h}$ PI and was below the normal limit between $8 \mathrm{~h}$ and $60 \mathrm{~h}$ PI in two animals. These findings are in agreement with those of Mills et al. (1998) and Patterson et al. (1988), whose research displayed a drop in PCV in horses with FCA-induced inflammation, but are different from those obtained in horses with endotoxemia induced by LPS injection, in which the mean PCV was not significantly different from the control values (Oliveira-Filho et al. 2012).

In our study, the leukocytosis that was observed after $48 \mathrm{~h}$ PI was caused by the increase in the number of neutrophils in the peripheral circulation as a result of the inflammatory stimulus. This response was similar to that observed in horses after two injections of Freund's adjuvant and is a typical systemic response to infection (Mills et al. 1998).

Inflammation results in an increase in the plasma concentration of several proteins that are released at the very beginning of the inflammatory stimulus, which are called acute phase proteins. Such proteins may be used as nonspecific markers of inflammatory processes (Patterson et al. 1988, Jacobsen et al. 2005). The quantification of plasma fibrinogen is commonly used in horses to indicate the presence of several diseases that cause inflammation (Schalm et al. 1970, Stoneham et al. 2001). The results from our study agree with other authors in that the fibrinogen values increased only $24 \mathrm{~h}$ after the induction of inflammation (Schalm et al. 1970, Auer et al. 1989). Other authors (Patterson et al. 1988, Mills et al. 1998, Oliveira-Filho et al. 2012) have also observed fibrinogen values above the normal limits $(400.0 \mathrm{mg} / \mathrm{dL})$ at the end of the experimental period.
The quick and dramatic hypoferremia that was observed at $16 \mathrm{~h}$ PI ( $50 \%$ of the initial value) and that reached its lowest value at $30 \mathrm{~h}$ PI (33\% of the initial value), was similar to several other studies inducing inflammation in horses (Varma et al. 1984, Smith et al. 1986, Smith \& Cipriano 1987, Auer et al. 1989, Mills et al. 1997a, Jacobsen et al. 2005). Moreover, the plasma iron concentration returned to normal levels four days after the first administration of FCA and remained within normal limits until the end of the experiment. We found quantification of plasma iron to be an earlier indicator of adjuvant induced inflammation in horses than measures of fibrinogen, similar to previous results (Varma et al. 1984, Smith et al. 1986, Smith \& Cipriano 1987, Auer et al. 1989, Jacobsen et al. 2005, Borges et al. 2007, Oliveira-Filho et al. 2012). The hypoferremia observed in the present study demonstrated a more persistent inflammatory process than the LPS model of inflammation in horses, as the iron levels returned to baseline $30 \mathrm{~h}$ after the LPS infusion (Oliveira-Filho et al. 2012).

The quantity of tissue obtained upon biopsy was sufficient for the extraction of RNA of an appropriate concentration and quality for molecular analysis. Equine $\beta$-actin has been used as an endogenous gene in previous studies in horses (Oliveira-Filho et al. 2010a, 2012). In our study, the $\beta$-actin gene displayed the same pattern of expression throughout the experiment, so its expression in the liver was not affected by the administration of FCA, making its use as a reference gene possible.

In humans, the peak urinary hepcidin expression was shown to occur $6 \mathrm{~h}$ after LPS infusion and was followed by a significant decrease in iron concentrations (Kemna et al. 2005). In rats, the peak expression of hepcidin mRNA was evident $4 \mathrm{~h}$ after LPS infusion, but a decrease in the iron concentration was detected $2 \mathrm{~h}$ after administration (Wang et al. 2008). In horses, the hepatic hepcidin expression was seven times higher than the control $6 \mathrm{~h}$ after LPS infusion (Oliveira-Filho et al. 2012). The administration of turpentine oil in mice (Nicolas et al. 2002, Nemeth et al. 2004) and rats (Merle et al. 2007) increased the mRNA expression of hepatic hepcidin three to 12 times and caused a drop in iron concentrations 16 hours after the injection of turpentine. In another study in rats, the mRNA expression of hepatic hepcidin was significantly higher than the control at $3 \mathrm{~h}$ and $12 \mathrm{~h}$ after the administration of turpentine, and it exhibited a peak (seven-fold) level of expression $6 \mathrm{~h}$ after the induction of inflammation (Sheikh et al. 2007). The determination of the biopsy sampling time in the present study was based on a preliminary study (Oliveira-Filho et al. 2010b) that showed, using a similar experimental proto$\mathrm{col}$, a statistically significant difference in serum iron levels at $8 \mathrm{~h}$ PI (50 \% of the initial value). In this previous study, the relative expression of hepcidin $\mathrm{mRNA}$ in the liver was up-regulated at $12 \mathrm{~h}$ and $24 \mathrm{~h}$ PI (two-fold), which was similar to that found in the present study. Thus, the relative expression of hepcidin mRNA appears to be stable between $6 \mathrm{~h}$ and $24 \mathrm{~h} \mathrm{PI}$ in horses subjected to the FCA protocol. Interestingly, the two-fold increase in hepcidin mRNA expression produced a similar decrease in the plasma iron as did the six-fold increase that was observed in the horses stimu- 
lated with LPS. However, the hepcidin response was longer lived in horses with inflammation induced by FCA than in horses with endotoxemia induced with LPS (Oliveira-Filho et al. 2012).

\section{CONCLUSIONS}

The results from our study indicated that the FCA administration protocol was sufficient to induce inflammation as characterized by clinical and laboratorial parameters.

We found that the iron plasma concentration decrease was an earlier and more sensitive measure of inflammatory processes in horses when compared with the fibrinogen increase and might be useful for the early detection of inflammation in the horse.

The hypoferremia observed in horses with FCA-induced inflammation was likely a consequence of the increase in the mRNA expression of hepatic hepcidin that was observed $6 \mathrm{~h}$ and $18 \mathrm{~h}$ after the first administration of FCA.

Acknowledgements.- This study was supported by grants from Fundação de Amparo à Pesquisa do Estado de São Paulo (FAPESP, 07/07344-6, 07/05008-9) and from Pro-Reitoria of the Univ. Estadual Univ. (Unesp) (process 1946/009/13-PROPe/CDC). The authors acknowledge Marcelo A. Pessoa (MP Reprodução Equina Ltda, Bauru) for loaning out the experimental animals.

\section{REFERENCES}

Auer D.E., Ng J.C., Thompson H.L., Inglis S. \& Seawright A.A. 1989. Acute phase response in horses: changes in plasma cation concentrations after localized tissue injury. Vet. Rec. 124:235-9.

Billiau A. \& Matthys P. 2001. Modes of action of Freund's adjuvants in experimental models of autoimmune diseases. J. Leuk. Biol. 70:849-860.

Borges A.S., Divers T.J., Stokol T. \& Mohammed 0.H. 2007. Serum iron and plasma fibrinogen concentrations as indicators of systemic inflammatory diseases in horses. J. Vet. Intern. Med. 21:489-494.

Bullen J.J., Rogers H.J., Spalding P.B. \& Ward C.G. 2005. Iron and infection: the heart of the matter. FEMS Immunol. Med. Microbiol. 43:325-330.

Darshan D. \& Anderson G.J. 2009. Interacting signals in the control of hepcidin expression. Biometals 22:77-87.

Dinarello C.A. 1999. Cytokines as endogenous pyrogens. J. Infect. Dis. 179: S294-S304.

Drakesmith H. \& Prentice A. 2008. Viral infection and iron metabolism. Nat. Rev. Microbiol. 6:541-552.

Feldman B.F., Zinkl J.G. \& Jain N.C. 2000. Schalm's Veterinary Hematology. Lippincott Williams and Wilkins, Baltimore. 1921p.

Jacobsen S., Jensen J.C., Frei S., Jensen A.L. \& Thoefner M.B. 2005. Use of serum amyloid $A$ and other acute phase reactants to monitor the inflammatory response after castration in horses: a field study. Equine Vet. J. 37:552-556.

Kemna E., Pickkers P., Nemeth E., Van der Hoeven H. \& Swinkels D. 2005. Time-course analysis of hepcidina, serum iron, and plasma cytokine levels in humans injected with LPS. Blood 106:1864-1866.

Merle U., Fein E., Gehrke S.G., Stremmel W. \& Kulaksiz H. 2007. The iron regulatory peptide hepcidin is expressed in the heart and regulated by hypoxia and inflammation. Endocrinology 148:2663-2668.

Mills P.C., Ng J.C., Kramer H. \& Auer D.E. 1997a. Stress response to chronic inflammation in the horse. Equine Vet. J. 29:483-486.

Mills P.C., Ng J.C. \& Auer D.E. 1997b. The effect of the acute-phase response on in vitro drug metabolism and plasma protein binding in the horse. Vet. Res. Communic. 21:361-368.

Mills P.C., Auer D.E., Kramer H., Barry D. \& Ng J.C. 1998. Effects of inflammation associated acute-phase response on hepatic and renal indices in the horse. Aust. Vet. J. 76:187-194.

Nemeth E., Rivera S., Gabayan V., Keller C., Taudorf S., Pedersen B.K. \& Ganz T. 2004. IL-6 mediates hypoferremia of inflammation by inducing the synthesis of the iron regulatory hormone hepcidin. J. Clin. Invest. 13:1271-1276.

Nicolas G., Chauvet C., Viatte L., Danan J.L., Bigard X., Devaux I., Beaumont C., Kahn A. \& Vaulont S. 2002. The gene encoding the iron regulatory peptide hepcidin is regulated by anemia, hypoxia, and inflammation. J. Clin. Invest. 110:1037-1044.

Oliveira-Filho J.P., Badial P.R., Cunha P.H.J., Cruz T.F., Araújo Jr. J.P., Divers T.J., Winand N.J. \& Borges A.S. 2010a. Cloning, sequencing and expression analysis of the equine hepcidina gene by real-time PCR. Vet. Immunol. Immunopathol. 135:34-42.

Oliveira-Filho J.P., Badial P.R., Cunha P.H.J., Cagnini D.Q., Silva J.R., Araújo Jr J.P., Divers T.J., Winand N.J. \& Borges A.S. 2010b. Hepcidin gene expression and plasma iron following intramuscular injection of Freund's complete adjuvant to horses [Abstract]. J. Vet. Intern. Med. 24:794.

Oliveira-Filho J.P., Badial P.R., Cunha P.H.J., Peiró J.R., Araújo Jr. J.P., Divers T.J., Winand N.J. \& Borges A.S. 2012. Lipopolysaccharide infusion up-regulates hepcidin mRNA expression in equine liver. Innate Immunity 18:438-46.

Patterson S.D., Auer D. \& Bell K. 1988. Acute phase response in the horse: plasma protein changes associated with adjuvant induced inflammation. Biochem. Int. 17:257-264.

Radtke A.L. \& O'Riordan M.X.D. 2006. Intracellular innate resistance to bacterial pathogens. Cell Microbiol. 8:1720-1729.

Rose R.J. \& Hodgson D.R. 2000. Manual Equine Practice. W.B. Saunders, Philadelphia. 818p.

Sang Y., Ramanathan B., Minton J.E., Ross C.R. \& Blecha F. 2006. Porcine liver-expressed antimicrobial peptides, hepcidina and LEAP-2: cloning and induction by bacterial infection. Dev. Comp. Immunol. 30:357-366.

Schaefer D.M.W. 2009. Iron metabolism and laboratory assessment of iron status. In Proceedings ACVP/ASVCP Concurrent Annual Meetings, Monterey, CA. Edited by American College of Veterinary Pathologists: Curran Associates Inc. , p.37-42.

Schalm O.W., Smith R. \& Kaneko J. 1970. Plasma protein: fibrinogen rations in dogs, cattle and horses. Part I. Influence of age on normal values and explanation of use in disease. California Vet. 24:9-11.

Sheikh N., Dudas J. \& Ramadori G. 2007. Changes of gene expression of iron regulatory proteins during turpentine oil-induced acute-phase response in the rat. Lab. Invest. 87:713-725.

Smith J.E. \& Cipriano J.E. 1987. Inflammation-induced changes in serum iron analyses and ceruloplasmin of Shetland ponies. Vet. Pathol. 24:354-356.

Smith J.E., Cipriano J.E., Debowers R. \& Moore K. 1986. Iron deficiency and pseudo-iron deficiency in hospitalized horses. J. Am. Vet. Med. Assoc. 188:285-287.

Stoneham S.J., Palmer L., Cash R. \& Rossdale P.D. 2001. Measurement of serum amyloid $\mathrm{A}$ in the neonatal foal using a latex agglutination immunoturbidometric assay: determination of the normal range, variation with age and response to disease. Equine Vet. J. 33:599-603.

Varma K.J., Powers T.E., Powers J.D. \& Spurlock S.L. 1984. Standardization of an experimental disease model of Streptococcus zooepidemicus in the equine. J. Vet. Pharmacol. Ther. 7:183-189.

Wang Q., Du F., Qian Z.M., Ge X.H., Zhu L., Yung W.H., Yang L. \& Ke Y. 2008. Lipopolysaccharide induces a significant increase in expression of iron regulatory hormone hepcidin in the cortex and substantia nigra in rat brain. Endocrinology 149:3920-3925 